\title{
Implementation of Fully Required Elements in the Crime of Planning Murder (Case Study in Blora State Court)
}

\author{
Beno $^{1}$, Gunarto ${ }^{2}$ and Sri Kusriyah ${ }^{3}$
}

Abstract: In principle, ordinary killings are different from premeditated killings, in terms of actions that kill the lives of others, but some are carried out in a timeframe, structured and planned. In this research, the formulation of the problem formed is how is the implementation of the requirements for the fulfillment of elements in criminal acts of premeditated murder? And what are the obstacles in deciding the case of premeditated murder in the Blora State Court In the research carried out, the writing uses a sociological juridical approach, that is research that uses the method of approach to the problem by looking at the norms or laws that apply and see the implementation of the facts contained in the field. The results of the study as an answer to the formulation of the problem are (1) The element with the first plan is not a form of deliberate but in the form of how to form intentions / Opzet which has 3 conditions namely the Opzet was formed after being planned in advance, after people planned (Opzet) in advance, and planning the implementation of the "Opzet" requires a rather long period of time. (2) The obstacles of the judge in prosecuting the perpetrators of the crime of planned murder come from internal and external factors.

Keywords: Fulfilled Requirements; Elements of Criminal Acts; Planned Murder.

\section{Introduction}

The State of Indonesia is a State of law, based on Article 1 Paragraph (3) of the 1945 Constitution of the Republic of Indonesia (hereinafter abbreviated as the 1945 Constitution). That every person who is in the territory of Indonesia must submit to the laws in force in Indonesia and no one can be immune to the law, and all actions must be based and have consequences in accordance with the laws and regulations in the Republic of Indonesia, which aim at realizing life society, nation, and the State which is orderly, prosperous, and just in order to achieve the State's objectives as mandated in the opening of the 1945 Constitution of the Republic of Indonesia.

Crimes against a person's soul result in death, as a result of one's death is prohibited and threatened with punishment by law. The term criminal act in Dutch can be referred to as "strafbaarfeit" which means an act that makes the culprit convicted. The definition of a criminal act is an act or act against applicable law, be it a violation or crime that can be prosecuted by criminal law or the provisions of the legislation. ${ }^{4}$

Speaking of crimes, especially killings, people used to kill in a simple way so that the murder case was easily revealed by the police, but, along with the development of

\footnotetext{
${ }^{1}$ Student of Master of Law, Universitas Islam Sultan Agung Semarang and Indonesian Police, email: pakbeno2806@gmail.com

${ }^{2}$ Lecturer of Faculty of Law, Sultan Agung Islamic University (UNISSULA), Semarang

${ }^{3}$ Lecturer of Faculty of Law, Sultan Agung Islamic University (UNISSULA), Semarang

${ }^{4}$ Sudarto, 1990, Hukum Pidana Indonesia, Yayasan Sudarto Faculty of Law UNDIP, Semarang, p. 39.
} 
society and science, the crime of murder also experienced developments that were followed in various ways ranging from simple methods to sadistic way with a variety of different motives. Murder is the deprivation or loss of one's life by another person which results in the malfunctioning of all vital functions of the limbs due to the separation of the spirit from the victim's body. ${ }^{5}$

According to Article 338 of the Criminal Code, murder is any act done intentionally to eliminate the lives of others. Besides killing is considered a very inhuman act. In a crime of murder, the target is the life of someone who cannot be replaced with anything. And the seizure is very contrary to the 1945 Constitution of the Republic of Indonesia which reads: "every person has the right to live and has the right to defend his life and life". If we look into the Criminal Code (KUHP), we can know that the legislator has intended to regulate the provisions of criminal crimes directed against that person's life in Book II Chapter XIX of the Criminal Code which consists of thirteen articles, ${ }^{6}$

In principle, ordinary killings are different from premeditated killings, in terms of actions that kill the lives of others, but some are carried out in a timeframe, structured and planned. Murder plans are listed in Article 340 of the Criminal Code "Anyone who intentionally and with prior plans take the life of another person, threatened with capital punishment or imprisonment for life live or for a certain time, a maximum of 20 years. "

Regarding the implementation of the premeditated murder, the reason is that the defendant's actions were not only about him taking away the lives of his victims but about the impact he caused it and the way he lost his life. Basically, in making a decision it is based on the belief of the judge, but why does the judge himself deny that the act is cruel, inappropriate and has a quite serious influence, not only on the victim's family but also on the community because the criminal sentence given by the judge is not in accordance with the mandate of the law both the Criminal Code and the Criminal Procedure Code.

Where in this case only incriminating matters are the basis of the judges' consideration and more preferably the element of the crime of murder must also be proven by the fulfillment of the elements of the plan for planning a crime. Because the planning requirements can be proven in determining whether the murder crime has been planned or not which affects the sentence to be given.

Based on the description on the background of the problem above, then the problem formulation can be formed as follows: How is the implementation of the requirements for the fulfillment of elements in criminal acts of premeditated murder? What are the obstacles in deciding the case of premeditated murder in the Blora State Court?

\footnotetext{
${ }^{5}$ Mustofa hasan and Beni Ahmad Saebani, 2013, Hukum Pidana Islam, Pustaka Setia, Bandung, p. 273.

${ }^{6}$ PAF Lamintang, Theo Lamintang, 2010, Kejahatan Terhadap nyawa, Tubuh dan Kesehatan, second edition, , Sinar Grafika, Jakarta, p. 11
} 


\section{Research methods}

In the research carried out, writing uses the Sociological Juridical approach, which is research that uses the method of approach to the problem by looking at the norms or laws that apply as positive provisions, the following theories that are relevant to this paper by linking their implementation to the facts contained in the field.

The research specifications used are descriptive analysis research. The data used for this study are primary and secondary data. Primary data is data obtained directly from the field or from the first source and has not been processed by other parties. Then secondary data is data obtained from library research consisting of primary legal materials, secondary legal materials and tertiary legal materials. To obtain data in this study, data collection methods are used, namely document collection, interviews, and literature study. The data that has been obtained is then analyzed by qualitative analysis.

\section{Results and Discussion}

\subsection{Implementation of Requirements for Fulfillment of Elements in Crimes of Planned Murder}

In the Criminal Code, especially the formulation that states "planned" as an element of crime. The criminal provisions referred to are contained in Article 340 of the Criminal Law Code. The article, the formulation is as follows: Anyone who intentionally and with prior plan seizes the lives of others, because of premeditated murder, is threatened with capital punishment, life imprisonment or a maximum sentence of twenty years. ${ }^{7}$ In this offense formula it can be concluded that the elements are: Whoever; Deliberately and plan ahead; Rooting other people's souls.

Delick that meets these three elements is given the name or quality of premeditated murder. The formulation of this offense, is another form or special form of offense or crimes against ordinary or general life is murder which is formulated in Article 38 of the Criminal Code as follows: "Anyone who intentionally seizes another person's life, for committing murder, is threatened with imprisonment a maximum of fifteen years". 8

The essence of the crime of murder is to deliberately take the life of another person or take the soul of another person. The existence of other forms of the crime of murder, lies not in essence but in certain circumstances both in how to do the deed and in the object of the deed. In the way of doing the act, the particular condition is the element

\footnotetext{
${ }^{7}$ SR Sianturi, 1983, Tindak Pidana di KUHP berikut uraiannya, Alumni of AHM. PT. HM. Jakarta, p. 489. ${ }^{8}$ Ibid, p. 485
} 
of planning, whereas in the killing of a child, the special situation is the object is a newborn child.

The existence of an intentional element is said: the intentional element includes its actions and their objects. This means that he knows and wants the death of someone with his actions. ${ }^{9}$ Regarding this element of intentionality it is said: In the literature there are generally recognized three intentional features: (1) intentionality as an intention, (2) intentionality as a necessity and (3) intentionality as a possibility.

In deliberate as the intent of the action was intentional because it was intended to achieve a goal. Deliberation as a necessity exists if the act done is not the intended one, but to achieve that intended one must do the same act. The intended path through the act, in intentional as the possibility of the criminal act, is not forced to be carried out, but only a possibility. ${ }^{10}$ If a person commits an action that is meant by not afraid of the possibility of committing a criminal act, then the said criminal act is done intentionally as a possibility. ${ }^{11}$

Planned murder in law is generally the most serious type of murder, and the perpetrators can be sentenced to death. The elements of premeditated murder under Article 340 of the Indonesian Criminal Code are:

- Whoever, is a legal subject where the legal subject that can be held accountable according to criminal law is the person Naturlijk, namely humans;

- Deliberately, is the perpetrator has the will and conviction to cause certain consequences that have been regulated in legislation that are driven by the fulfillment of passions (motives);

- With advance planning, it means that there is a pause between planning and action that allows for systematic planning first and then followed by action. ${ }^{12}$

Based on the results of the author's interview with Yayuk Musyafiah, a Blora State Court judge who said that the element with prior planning is not a form of deliberate but a way of forming intentions / Opzet which has 3 conditions namely:

- Opzet 'it was formed after being planned in advance;

- And after people have planned it (Opzet) in advance, the important thing is the way the "Opzet" is formed which must be in a calm state;

- And in general, planning the implementation of the "Opzet" requires a rather long period of time. ${ }^{13}$

Noting the understanding and conditions of the elements planned in advance above, it appears that the process of formation was planned in advance (planning) is indeed

\footnotetext{
${ }^{9}$ Ibid, p. 485

${ }^{10}$ Frangky Maitulung, 2013, Penanganan Terhadap Pelaku Tindak Pidana Pembunuhan Yang Dilakukan Psikopat, Jurnal Hukum, Sam Ratulangi University, Vol. II, November 7, p. 129

${ }^{11}$ Roeslan Saleh, 1981, Perbuatan Pidana dan Pertanggung jawaban Pidana, Centra, Jakarta, p. 123

12 HAK Moch Anwar, 1989, Hukum Pidana Bagian Khusus (KUHP buku II), PT Citra Aditya Bakti, Bandung, p. 56

${ }^{13}$ Results of an Interview with Yayuk Musyafiah, $\mathrm{SH}, \mathrm{MH}$, Judge of the Blora District Court, on 4 December 2019
} 
different from the formation of deliberate (will). Planned murder is considered an independent murder and is different from ordinary killings in the principal form of Article 338 of the Criminal Code moreover the planned murder is referred to by lawmakers as a special incriminating murder case. The purpose of the law incriminates the threat of Article 340 of the Criminal Code not only lies in the act of planning, but the time used to prepare a plan, because the opportunity to reduce the intention is not implemented.

\subsection{Constraints in Deciding the Case of a Criminal Act of Murder in the Blora State Court}

In the results of an interview with Judge PN Blora Yayuk Musyafiah, the obstacles of the judge in prosecuting perpetrators of criminal acts of premeditated murder came from internal and external factors in the form of:

\subsubsection{Internal factors ${ }^{14}$}

Internal factors are factors that occur from within the judge himself. This barrier is based on because judges are also human beings who have compassion or compassion, especially criminal acts committed by perpetrators, judges must have maturity in heart and mind because in order to unite a fair decision the ruling has a sense of justice for everyone.

The crimes committed by the perpetrators are mostly due to environmental, family, and economic factors. These factors become barriers for judges in providing punishment for murder committed by perpetrators. The obstacle of the judge himself because in dropping the verdict I think that the defendant still has a long life or future, so there are still many things or opportunities and time for the offender to improve himself and become a good person. This affects the judge where the judge feels there will be a reduction in punishment against the offender, but on the other hand the judge must also empathize with the victim's family. The judge in giving punishment is the factor of heart that will speak.

But according to Judge Yayuk in a criminal act of premeditated murder, the judge as a human being also has an emotional level to see the actions taken by the perpetrators with various motives in which the judge's emotional will appear when he sees the motives and intentions of the perpetrators who killed the victims inhumanely without at all thinking like humans and out of common sense affects the maximum sentence in this regard.

\subsubsection{External Factors ${ }^{15}$}

\footnotetext{
${ }^{14}$ Results of an Interview with Yayuk Musyafiah, $\mathrm{SH}, \mathrm{MH}$, Judge of the Blora District Court, on 4 December 2019

${ }^{15}$ Results of an Interview with Yayuk Musyafiah, $\mathrm{SH}, \mathrm{MH}$, Judge of the Blora District Court, on 4 December 2019
} 
In the courtroom that took place, many parties involved and concerned in the case. Starting from the defendant, witnesses, public prosecutors, to lawyers. But it can also be obstacles that arise from other parties, namely:

- Defendant's Statement

During the trial the judge needed information from the defendant himself about the criminal act he committed. The defendant's statement may not be in accordance with what he said, for that the Judge must be observant in examining how the defendant's statement.

- Witness Statement

The judge has obstacles in hearing the testimony of the witness if the witness does not testify according to what should have happened, the witness who provides a convoluted explanation that can make it difficult for the judge to draw conclusions from the witnesses 'explanations, and not the least of the witnesses' different testimonies from the statements in the proceedings, where during the examination process the witness gave different information so there was the inclination of the witness not to admit the explanation he gave outside the trial. For this reason, the Judge must also be able to connect or harmonize one witness with another.

- Evidence

Constraints Factors experienced by the judge are material evidence that is incomplete or that has been lost, this is an obstacle for the Judge because the more evidence the easier it is to resolve the case and vice versa.

As for efforts to overcome existing obstacles, the Judge can see the statements of the Public Prosecutor, and conduct deliberations with other Judges to provide appropriate considerations and decisions to the parties at the hearing, so that the judge's decision can be accepted by all parties who there is. ${ }^{16}$ According to Judge Yayuk, in all its constraints and considerations the judge basically decides on a criminal case to aim at a fair justice. Because actually justice as a human reasoning and God's will to provide punishment that affects the lives of perpetrators and victims. ${ }^{17}$

\section{Closing}

\subsection{Conclusions}

- The element with advance planning is not a form of intent, but it is a way of forming intentions / Opzet which has 3 conditions, namely:

- The Opzet was formed after it was planned in advance;

\footnotetext{
${ }^{16}$ Results of an Interview with Yayuk Musyafiah, $\mathrm{SH}, \mathrm{MH}$, Judge of the Blora District Court, on 4 December 2019

${ }^{17}$ Pan Mohamad Faiz, 2009, "Teori Keadilan John Rawls", in Journal of the Constitution, Volume 6 Number 1, p. 139.
} 
- And after people plan (Opzet) in advance, then the important thing is how the "Opzet" is formed, which must be in a calm state;

- And in general, planning the implementation of the "Opzet" requires a rather long period of time.

- The obstacles of the judge in trying the perpetrators of the crime of planned murder come from internal and external factors in the form of internal factors which are factors that occur within the judge himself. This barrier is based on because judges are also human beings who have compassion or compassion, especially criminal acts committed by perpetrators, judges must have maturity in heart and mind because in order to unite a fair decision the decision has a sense of justice for everyone, and external factors from the defendant's statement it may not be in accordance with what he said, for that the Judge must be observant in examining how the defendant's statement, witness statements that provide convoluted explanations that can make it difficult for judges to draw conclusions from the witnesses' explanations,

\section{Suggestions}

- For the upcoming Criminal Law, it is not necessary to include the element of planning as an element of offense to distinguish the weight of the threat of punishment between planned and unplanned because of the quality of today's killings between planned and non-equal even the fact that unplanned killings are sometimes more sadistic than planned killings so he was given a heavier sentence;

- It is necessary to add material in the Criminal Code which regulates murder where it is necessary to set clear substance to the parameters of the sadistic method of killing the victim with the initial planning which is the most severe sentence.

\section{References}

\section{Books}

[1] HAK Moch Anwar, 1989, Hukum Pidana Bagian Khusus (KUHP buku II), PT Citra Aditya Bakti, Bandung.

[2] JESahetapy, 1982, Suatu Studi Khusus Mengenai Ancaman Pidana Mati Terhadap Pembunuhan Berencana, CV. Rajawali, Jakarta.

[3] Mustofa hasan and Beni Ahmad Saebani, 2013, Hukum Pidana Islam, Pustaka Setia, Bandung.

[4] PAF Lamintang, 2010, Theo Lamintang, Kejahatan Terhadap nyawa, Tubuh dan Kesehatan, Sinar Grafika, Jakarta.

[5] Roeslan Saleh, 1981, Perbuatan Pidana dan Pertanggung jawaban Pidana, Centra, Jakarta.

[6] SR Sianturi, 1983, Tindak Pidana di KUHP berikut uraiannya, Alumni of AHM. PT. HM. Jakarta. 
[7] Sudarto, 1990, Hukum Pidana Indonesia, Yayasan Sudarto Faculty of Law UNDIP, Semarang.

\section{Statutory Regulations}

[1] The 1945 Constitution of the Republic of Indonesia

[2] Criminal Law Book

\section{Journal}

[1] Frangky Maitulung, Penanganan Terhadap Pelaku Tindak Pidana Pembunuhan Yang Dilakukan Psikopat, Journal of Law, Sam Ratulangi University, Vol. II, November 7, 2013.

[2] Pan Mohamad Faiz, "Teori Keadilan John Rawls", in the Constitutional Journal, Volume 6 Number 1, 2009. 